Meta

Journal des traducteurs

Translators' Journal

\title{
On Representing Aesthetic Values of Literary Work in Literary Translation
}

\section{Huijuan Ma}

Volume 54, numéro 4, décembre 2009

URI : https://id.erudit.org/iderudit/038897ar

DOI : https://doi.org/10.7202/038897ar

Aller au sommaire du numéro

\section{Éditeur(s)}

Les Presses de l'Université de Montréal

\section{ISSN}

0026-0452 (imprimé)

1492-1421 (numérique)

Découvrir la revue

Citer cet article

Ma, H. (2009). On Representing Aesthetic Values of Literary Work in Literary Translation. Meta, 54(4), 653-668. https://doi.org/10.7202/038897ar
Résumé de l'article

La beauté de la traduction littéraire est déterminée par la nature artistique du texte original. Ainsi, la représentation des valeurs esthétiques du texte original doit être considérée comme l'objectif ultime de la traduction littéraire. Le présent article se fonde, sur le plan théorique, sur les éléments esthétiques formels et non formels de la littérature classifiés par le traductologue chinois Liu Miqing ainsi que par la philologie chinoise traditionnelle et la stylistique littéraire moderne. Il explore en détail les méthodes de représentation des valeurs esthétiques littéraires sous deux angles, soit les marques esthétiques formelles et les marques esthétiques non formelles. Il révèle que, puisque dans une oeuvre littéraire les marques formelles et non formelles sont vraiment inséparables, une combinaison adéquate de celles-ci peut produire une solution satisfaisante. 


\title{
On Representing Aesthetic Values of Literary Work in Literary Translation
}

\author{
HUIJUAN MA \\ Beijing Foreign Studies University, Beijing, China \\ mahuijuan@bfsu.edu.cn
}

\begin{abstract}
RÉSUMÉ
La beauté de la traduction littéraire est déterminée par la nature artistique du texte original. Ainsi, la représentation des valeurs esthétiques du texte original doit être considérée comme l'objectif ultime de la traduction littéraire. Le présent article se fonde, sur le plan théorique, sur les éléments esthétiques formels et non formels de la littérature classifiés par le traductologue chinois Liu Miqing ainsi que par la philologie chinoise traditionnelle et la stylistique littéraire moderne. Il explore en détail les méthodes de représentation des valeurs esthétiques littéraires sous deux angles, soit les marques esthétiques formelles et les marques esthétiques non formelles. II révèle que, puisque dans une œuvre littéraire les marques formelles et non formelles sont vraiment inséparables, une combinaison adéquate de celles-ci peut produire une solution satisfaisante.
\end{abstract}

\section{ABSTRACT}

The beauty of literary translation is determined by the artistic nature of the original work. Therefore, how to represent its aesthetic values should be considered the ultimate objective of literary translation. This paper, which is theoretically based on formal and nonformal aesthetic constituents of literature classified by the Chinese translation theorist Liu Miqing as well as traditional Chinese philology and modern literature stylistics, discusses extensively how to succeed in representing aesthetic values of literary works from two aspects, i.e., formal aesthetic markers and non-formal aesthetic markers. It also points out that since in a literary work formal markers and non-formal markers are really inseparable, the proper combination of the two can provide a satisfactory solution.

\section{MOTS-CLÉS/KEYWORDS}

traduction littéraire, valeurs esthétiques, marques esthétiques formelles, marques esthétiques non formelles

literary translation, aesthetic values, formal aesthetic markers, non-formal aesthetic markers

It is commonly acknowledged that a literary work is a creative art of language. Without the inherent elements of aesthetic values the literary work cannot be termed as an art. Lu Xun, a great Chinese writer, says that literature is an art of beauty with three beautiful features, i.e., beautiful thought that appeals to the heart, beautiful sound that pleases the ear, and beautiful form that attracts the eye (Xu 1989: i). Leech and Short (1981: 23-24) present an equation to illustrate the crucial role of stylistic values in literary work:

\section{SENSE + STYLISTIC VALUE $=($ total $)$ SIGNIFICANCE}

Sense here refers to "the basic logical, conceptual, paraphrasable meaning"; significance refers to "the total of what is communicated to the world by a given sentence or text," and stylistic value is "a writer's choice to express his sense in this rather than 
that way" (Leech and Short 1981: 23-24). According to Leech and Short, it is stylistic value that distinguishes the uniqueness of a literary work. To illustrate this point, let us see a much-quoted sentence by the Founding Father Thomas Paine, and its four paraphrases by the American writer E. B. White:

These are the times that try men's souls

(Paine 2006)

1. Times like these try men's souls.

2. How trying it is to live in these times!

3. These are trying times for men's souls.

4. Soulwise, these are trying times.

(Strunk and White 1972: 60)

The four paraphrases (1-4) are grammatically perfect statements, expressing the basic idea of Paine's sentence. However, each of the four versions proposed for comparison is, as White puts it, "marked for oblivion," while the original has been quoted and requoted for over two hundred years and is now well along into its third century (Strunk and White 1972: 60). The success of Paine's writing is due to its stylistic value, i.e., the proper arrangement of words and its sound effects. Similarly, if a translated literary work possesses no aesthetic value, it would read dull and tasteless, and be doomed to oblivion. Let us look at two examples:

(1) Ignatiev saw red: this was the man who had killed Sedov, who in a single night had set fire to a big and lovely city, who had murdered the beautiful Ukrainian girl, who had trampled down the field, razed the white cottages, brought shame and death to the people. (Vasili Grossman: The People Immortal)

$\mathrm{V} 1$ : 伊格那季亦夫的眼睛发暗了, 一但是这人曾杀死歇陀夫, 他曾在一夜之中纵火 焚烧一座大城市, 他杀死一个美丽的乌克兰女子, 他曾践踏田野, 破毁村舍, 他给 民众送来耻辱和死亡 (Translated by Li Ling)

V2: 伊格那底也夫是仇人见面, 分外眼红。杀塞度夫的, 是这家伙; 一夜之间毁灭 了一座大而美丽的城市的, 杀害了那美丽的乌克兰姑娘的, 也是这家伙; 践踏了麦 田, 夷平了白色的村舍, 侮辱和屠杀人民的, 也是这家伙呀! (Translated by Mao Dun)

V1 merely translates the sense of the original text, but fails to express the feeling of the character. In comparison, V2 successfully conveys the character's deep hatred. By putting the original emphatic sentence this was the man who...who...who... into parallel structure 杀...的, 是这家伙; 一夜之间毁灭了...的, 杀害了...的, 也是这家 伙; 践踏了.... 夷平了...的, 也是这家伙呀!, the translator of V2 highlights the hero's indignation at the atrocity of the enemy. In addition, V2 satisfactorily represents the rhythm of the original text (Zhang 1987: 127).

(2) 一言未了, 早见宝玉跑至围屏灯前, 指手画脚, 满口批评, 这个这一句不好, 那一个 破的不恰当, 如同开了锁的猴子一般。(曹雪芹《红楼梦》第22回)

V1: Pao-yu had already run up to the screen-lantern and was prancing about like a monkey freed from its chain, pulling different riddles to pieces. (Translated by Xianyi Yang and Gladys Yang)

V2: And the words were no sooner out of her mouth than Bao-yu leaped up from his seat and over to the screen and began criticizing the riddles on it - this one had a line wrong here - that one's words didn't suit the subject - pointing with his finger and capering about for all the world like a captive monkey that had just been let off its chain. (Translated by David Hawkes) 
At the Jia family get-together on the day of the Lantern Festival, Bao-yu dared not to talk and laugh as he pleased, overwhelmed by the presence of his severe father Jia Zheng. The moment his father was dismissed by Grandmother, Bao-yu jumped out of his seat and began to air his views about the riddles. Although both versions convey the metaphor 如同开了锁的猴子一般 (The Yangs put it as prancing about like a monkey freed from its chain, and Hawkes renders it as capering about for all the world like a captive monkey that had just been let off its chain), the Yangs' version, to my mind, is not as vivid as Hawkes', for Bao-yu's actions 指手画脚, 满口批评, 这个 这一句不好, 那一个破的不恰当 are rendered merely into pulling different riddles to pieces, without preserving the original imagery; whereas Hawkes' translation, began criticizing the riddles on it - this one had a line wrong here - that one's words didn't suit the subject - pointing with his finger, successfully represents Bao-yu's great rejoicing in his father's absence.

The two examples above strongly indicate that the quality of literary translation depends on the successful representation of aesthetic values. Only when aesthetic values of the original text are satisfactorily conveyed in the receptor language can the reader of the translated text have similar response as the original reader. Liu Shicong (2000: 73) says that literary translation requires "not only linguistic correctness, but also aesthetic appeal." Zhang also claims that in literary translation, many factors that have to be considered

fall in with aesthetics and art. In a word, to neglect the artistic nature of literary translation is to neglect its social function and, if that is the case, it is bound to end up in formalism of translation, thus reproducing works that are linguistically correct but artistically pale and weak (Zhang 1987: 16; translated by Liu Shicong).

There is no exaggeration to say that the success of literary translation depends to a large extent on the successful representation of aesthetic values, and transference of aesthetic elements is the prerequisite of a literary translation.

As early as the seventeenth century, John Dryden stated that the translator should make his translation graceful "by the spirit which animates the whole" (Kelly 1979: 206-209). C. W. Orr likened translating to painting, and claimed that the painter did not reproduce every detail of the landscape, but selected what seemed best to him. Likewise, the translator sought to embody in his own version "the spirit, not only the letter" (Nida 1964: 162). However, up to now, there are few systematic or satisfactory discussions about the transference of stylistic values in the west (SnellHornby 1988: 119-120).

By comparison, in the field of traditional Chinese translation theory there have been abundant discussions about transference of aesthetic values or spirit. From Yan Fu's faithfulness, expressiveness and elegance through Lin Yutang's fidelity, smoothness and beauty to Zhu Shenghao and Fu Lei's spirit resemblance and Qian Zhongshu's sublimation, all emphasized the importance of transference of spirit in translating. In a sense, the focus of Chinese traditional translation theories is on the successful representation of the spirit or aesthetic values of literary text. Regrettably, most discussions about spirit transference have not gone beyond the sphere of the translator's subjective perception and appreciation. Such terms as 雅, 意境, 神韵, 神似, 化境, borrowed from Chinese classic literary criticism and painting criticism, are characterized by fuzziness and do not provide any practical approach as to how to reach for the objective of spirit resemblance. 
There is no denying that it is not an easy task for the translator to convey the aesthetic values of literary work. Sidney Shapiro, the translator of Outlaws of the Marsh, says, when talking about the difficulty of literary translation, that what common readers want from a translation of a foreign classic, "in addition to the story itself, is the 'feel' of an ancient people in a distant land, a sense of the style of the original. That, for the translator, is infinitely more difficult than a mere accurate rendition of plot-line" (Shapiro 1993: viii). Difficult as it is, this does not mean that it is not possible to represent aesthetic values. As V2 in the examples above illustrate, the competent translators have done it very well and produced a number of excellent literary works for us. In the following section, we will examine how aesthetic values of literary works can be transferred in another language.

Liu Miqing has classified aesthetic values into formal aesthetic constituents and non-formal aesthetic constituents. Formal constituents are visible and audible; while non-formal constituents are "of a non-material nature that cannot be felt by intuitive association (直觉联想) alone but by intuitive imagination (直觉想象) - the upgraded intuitive association" (Liu Miqing 1995: 7). Liu’s classification is insightful, pointing the way to the objective analysis of aesthetic elements of literary work in a scientific manner. Based on his classification, the transference of aesthetic values can be dealt with from two aspects, i.e., formal aesthetic markers and non-formal aesthetic markers. Formal markers are perceptible aesthetic features, which can be identified by salient formal features such as choice of words, syntactical structures and textual construction, etc. The translator can make every effort to produce a functional equivalent translation in terms of aesthetic effect of formal markers. Non-formal markers are intangible aesthetic features that the reader can feel, but find it difficult to pinpoint where the beauty resides in a text. Such terms as 风骨, 气质, 精神, 神韵 in traditional Chinese classical aesthetics are the most appropriate expressions in describing these features. These remarks 不着一字, 尽得风流 (The spirit flows without expressions of words), 羚羊挂角, 无迹可求 (The reader cannot trace the word for the spirit of a literary text) actually refer to non-formal aesthetic elements in literary work. A great work of art possesses these two kinds of aesthetic markers, hence the quality of literary translations depends in large measure on the successful representation of these aesthetic markers. In the following section, we will deal with at length how these features can be satisfactorily transferred into another language.

\section{Transferring formal aesthetic markers}

As artistic beauty of a literary work is achieved through language, the translator can give an objective analysis of detailed working of its stylistic effects by means of linguistic description, and recognize where the beauty resides in the text. Liu Xie, an ancient Chinese philologist, states that the spirit of a text can never go without language:

Sentences are made up of words, paragraphs of sentences and a whole article of paragraphs. That an article is excellent is due to its flawless paragraphs, that a paragraph is fine is due to its blemishless sentences and that a sentence is good is due to proper words (Liu Zhongde 1991: 123; translated by Liu Zhongde).

Formal aesthetic markers are perceptible through choice of words, syntactical structures, rhetorical devices and texture of a text. In my view, the translator can convey 
aesthetic values by means of formal makers at five levels, namely, phonological, lexical, syntactical, rhetorical, and textual level.

\subsection{Phonological level}

Phonological beauty is one of the important elements that contribute to the artistic quality of literary work. The British writer W. Somerset Maugham states, "words have weight, sound and appearance; it is only by considering these that you can write a sentence that is good to look at and good to listen to" (Wu, Ding et al. 1980: 78). Zhu Guangqian (1984: 356) also says that the spirit of language depends largely on sound and rhythm, which are the most direct means to convey the feelings of the writer and the flavor of the text. If a translator wants to achieve an equivalent effect at the phonological level, he should strive for the representation of sound effect and rhythm of the original in his work. Let us look at some examples:

（3）排了队的小浪）挤到沙滩边, 皮澌! - — 队伍解散, 喷着忿怒的白沫。......( 满海 全是金眼睛, 全在跳跃。) 海塘下空隆空隆的腾起了喊杀。...... 不知到什么地方去 过一次的风, 忽然又回来了, 这回是打着鼓似的: 勃仑仑, 勃仑仑! (茅盾《黄昏》)

V1: They crowded forward to break against the beach. Then their troop scattered, spraying angry white foam [...] Clarion battle cries rose up from below the sea-wall. [...] The wind which had flown off somewhere abruptly came back, this time as if sounding a tattoo on a drum. (Translated by Niu Jin)

V2: They rush to the sandy beach-splash! The marching ranks scatter and burst into angry spray. [...] Rumble-rumble beneath the jetty a battle cry bursts forth. [...] The wind, having gone no-one-knows-where, suddenly returns, returns as a beating drum: boom-lum-lum, boom-lum-lum! (Translated by Hao Qicheng and Katherine Boller)

There are three types of prose: prose of feeling, of sound and of shape. The excerpt from Mao Dun's Dusk belongs to the type of sound. When reading it, one can hear various sounds in the sea before a heavy storm. By reproducing the correspondent onomatopoeia (such as splash for 皮澌, rumble-rumble for 空隆空隆, and boom-lumlum, boom-lum-lum for 勃仑仑, 勃仑仑”), the translators of V2 strive for an equivalence of sound effect. By comparison, V1 fails to convey the sound effect of the original, for it does not reproduce the original onomatopoeia.

(4) (二人归坐), 先是款勘漫饮, 渐次谈至兴浓, 不觉飞觥限嘏起来。(曹雪芹《红 楼梦》第1回)

At first they were rather slow and ceremonious; but gradually, as the conversation grew more animated, their potations too became more reckless and uninhibited. (Translated by David Hawkes)

The gentleman Zhen Shiying invites his poor friend Jia Yucun to have a drink on the night of the Mid-Autumn Festival. The Chinese sentence reads pleasant to the ear, and its rhythm is like flowing water, which is at first slow and then grows gradually rapid, vividly depicting the scene of their drink. By using stressed and unstressed syllables alternatively and adopting such sentence pattern as "At first... rather slow and ceremonious" and "but gradually...more reckless and uninhibited," the translator succeeds in reproducing the rhythm of the original, reflecting the phonological beauty of the Chinese sentence. 


\subsection{Lexical level}

Words play a significant role in transferring the spirit of a literary text. In order to convey the spirit, the writer usually selects the most appropriate words to express his meaning. The ancient Chinese writer attaches great importance to wording; and the Western writer also suggests "every word tells" (Strunk and White 1972: ix-x). Therefore, in translating literary works, the translator should pay special attention to the diction of the writer, especially words which have special aesthetic effect. The following two examples illustrate how the translators successfully represent the spirit of the words with special aesthetic effects:

(5) 街行见两措大执争一理, 既皆目裂颈赤,如不戴天, 而又高拱手, 低曲腰, 满口仍用 “者”、“也、“之”、“乎”等字。(金圣叹 《三十三不亦快哉》)

I am walking in the street and see two wretched scholars engaged in a hot argument of words with their faces flushed and their eyes staring with anger as if they were mortal enemies, and yet they still pretended to be ceremonious to each other, raising their arms and bending their waists in salute, and still using the most polished language of 'thou' and 'thee' and 'wherefore' and 'Is it not so?' (Translated by Lin Yutang)

The empty words者, 也, 之, 乎 are only used in classic Chinese language. It seems impossible to produce a rendering that has an equivalent effect in another language. Lin's version is a success, because he adopts the archaic English words thou, thee and wherefore and habitual expression is it not so to depict the two pedantic scholars. It can be clearly noted that Lin's rendering has retained the spirit of the original at the lexical level.

(6) 倪二道: “不妨不妨, 有什么不平的事, 告诉我, 替你出气。这三街六巷, 凭他是谁, 有人得罪了我醉金刚倪二的街坊, 管教他人离家散。”(曹雪芹 《红楼梦》第 24回）

'Nemmind!' said Ni Er. 'Anyone been bothering you, Mist' Jia, jus' tell me and I'll settle accounts with him for you! You know me. Ni Er. The Drunken Diamond. Old Dime'll look after you. Anyone this part of the town troubling neighbour of Dime's, don't care who he is, guarantee put him out of business.' (Translated by David Hawkes)

Jia Yun is annoyed with his uncle's refusal to lend him money when he runs into his neighbor the drunken Ni Er. After Jia tells Ni he has been unfairly treated, Ni promises to get revenge on the man who has wronged him. Hawkes vividly reproduces the drunkenness of Ni Er by using such irregular words as Nemmind, Mist, jus', Dime, and ungrammatical sentences as Anyone been bothering you. It is safe for us to say that Hawkes' version achieves the objective of equivalent effect.

\subsection{Syntactical level}

The writer resorts to various syntactical structures for artistic effects. In translating, one should first analyze how the literary writer arranges his sentences, and why he expresses his idea in this way rather than that way, then he may choose to follow closely the original syntactical structure, or make some readjustments to convey the artistic effect that the writer intends to accomplish. 
(7) 操曰: “龙能大能小, 能升能隐; 大则兴云吐舞, 小则隐介藏形; 升则飞腾于宇宙之 间, 隐则潜伏于波涛之内。方今春深, 龙乘时变化, 犹人得志而纵横四海。龙之为 物, 可比世之英雄”。(罗贯中《三国演义》第21回)

"The dragon," Cao continued, "can enlarge and diminish itself, surge aloft or lie beneath the surface of the water. Enlarged, it creates clouds and spews mist. Diminished, it can veil its scaly form from view. Aloft, it prances triumphant in the upper realm of space. Under the surface, it lurks among the surging breakers. Now in the fullness of spring it mounts the season, like men who would fulfill an ambition to dominate the length and breadth of the land. In this respect the dragon can well be compared to the heroes of the age." (Translated by Moss Roberts)

Cao compares the dragon to the heroes of his age. The first sentence narrates the dragon's four capabilities: to enlarge, diminish, surge aloft and lie beneath. The following clauses specifically describe the capabilities in parallel structures. The translator succeeds in representing the balancing beauty of the original by following closely the Chinese syntactical structures and putting the expressions of the four capabilities at the beginning of each clause, as the underlined words or phrases show.

(8) Let me come to the point boldly; what governs the Englishman is his inner atmosphere, the weather in his soul. (George Santanyana, The Weather in his Soul)

V1: 让我直截了当地谈正题吧: 是什么左右着英国人的言行举止? 是他内心的情 绪, 是他灵魂里的气候。(Translated by Liu Shicong)

$\mathrm{V} 2$ : 直截了当地说, 左右英国人一言一行的是他内心深处的感情, 他心灵里的气候。 (Student's Translation)

V3: 开门见山地说吧: 主宰英国人一切言行的是其内心中的气与气候。(Student's Translation)

The meaning of each version is more or less the same as the original, but, by comparison, V1 is a more satisfactory rendering. Although V2 and V3 adhere closely to the English syntactical structure, they are not so forceful as the original. The translator of V1 highlights the emphasis of the original by using a rhetorical question 是什么左右着英国人的言行举止? 是他内心的情绪, 是他灵魂里的气候, thus achieving an equivalent effect in terms of the force of the writer's language.

\subsection{Rhetorical level}

Rhetorical devices are deviations of normal expressions, with the intent to create an impact upon the reader by foregrounding. It is advisable for the translator to replace rhetorical devices with their functional equivalents in another language. Otherwise, the forcefulness of the original rhetorical devices will be impaired. For example:

(9) Intellectual assimilation takes time. The mind is not to be enriched as a coal barge is loaded. Whatever is precious in a cargo is carefully on board and carefully placed. Whatever is delicate and fine must be received delicately and its place in the mind thoughtfully assigned. (Arlo Bates)

V1: 吸收知识要从从容容, 不能象驳船装煤那样来填塞大脑。我们应小心地把珍 贵的货物装上船, 并谨慎地安放好。吸收精华时必须敏感, 而且要在头脑中加以周 密安排。(Translated by Huang Ren)

$\mathrm{V} 2$ : 汲取知识需要花费时间。人的头脑不能象驳船装煤那样一股脑填满。装贵重 货物时应当小心搬运、谨慎安放; 而精致易碎的货物则应悉心收纳, 妥当安置。

(Translated by the author) 
This paragraph consists of four sentences. In the second sentence, The mind is not to be enriched as a coal barge is loaded is a basic metaphor. The third and fourth are metaphorical descriptions of the means by which knowledge is acquired. In V1, the metaphorical image is kept in the third sentence but lost in the fourth. In terms of the overall effect of the metaphor, V1 fails to represent the rhetorical force. In contrast, V2 more satisfactorily conveys the metaphorical images and retains the wholeness of the metaphor in the original.

(10) 只见府门洞开, 两边灯笼照如白昼, 乱哄哄人来人往, 里面哭声摇山震岳。（曹雪 芹《红楼梦》第13回)

Arriving in haste at the entrance of the Ning-guo mansion, they found the gates flung wide open and lanterns on either side turning the night into noonday. Despite the hour, a multitude of people were hurrying through it in both directions, while from inside the house issued a sound of lamentation that seemed to shake the very buildings to their foundations. (Translated by David Hawkes)

When Qin Keqing, the favorite daughter-in-law of Jia Zhen, passed away, the whole family was busy preparing for her funeral. Metaphor and hyperbole are employed in this simple sentence. By putting the metaphorical expression 两边灯笼 照如白昼 as lanterns on either side turning the night into noonday, and the hyperbolic expression 哭声摇山震岳 as a sound of lamentation that seemed to shake the very buildings to their foundations, Hawkes succeeds in rendering these two rhetorical devices in his English version.

\subsection{Textual level}

At textual level, we are mainly concerned with cohesiveness and coherence. Since Chinese and English belong to different language families, the links between sentences in a Chinese text and in an English text are quite different. Nida rightly points out:

For Chinese and English, perhaps one of the most important linguistic distinctions is the contrast between the hypotaxis and parataxis. In English and in most IndoEuropean languages, a great deal of subordination is clearly marked by conjunctions such as, if, although, because, when, in order to, so and so that. One may, however, communicate essentially the same concepts by means of parataxis; that is to say, placing two propositions together without marking the relationship but indicating by content what is the evident relationship (Nida 1982: 23).

Due to these differences between English and Chinese, the translator could add connectives when translating from Chinese into English, or omit unnecessary connectives when going the other way round. Besides conjunctions, other cohesive devices (such as reference, substitution, ellipsis and lexical cohesion) also play a decisive role in constructing a text. In order to produce a translation with good texture, the translator should pay special attention to the problem of cohesive devices and coherence in translating. Here we will take a Chinese passage and its English rendering as an illustration:

（11）容闪回国后, 看到了清政府的腐朽落后和国家的贫弱。面对现实, 他忧国忧民。对 比中西社会, 他认识到, 要使中国富裕强盛, 就必须向西方学习。当时他的主张主 要有两点: 一是培养通晓西方文化科学知识的各种人才, 二是引进西方先进技术, 发展民族工业和交通运输业。为了实现自己的主张, 容闪不辞辛劳, 四处奔走、寻 
受可行的途径。就在这时, 曾国藩为了兴办洋务, 广泛招聘人才。向容闪发出了邀 请。1863年9月, 容闪应邀到达安庆, 入曾国藩大营。

到安庆后, 容闳向曾国藩提出了建立机器工厂的建议, 这个建议与曾国藩建立近 代兵工厂的想法基本一致, 曾国藩即授予他出洋购办机器的全权。1865年, 容闪 从美国订购回了100多种机器, 为江南制造总局提供了主要设备。

除了兴办近代工业企业, 容闳还十分注重培养西学人才。他两次提议清政府派遣 留学生赴美学习。清政府采纳了他的建议, 几年内先后派遣了120名官费留学生, 还任命容闪任中国留学事务所副监督。(《容厺》)

But Rong Hong returned only to witness a corrupted and backward government and a weak and impoverished country. The stark reality set him worrying about it and its people. He realized, by the sharp contrast between China and the West, that if China ever hoped to become a strong and prosperous country, it had to learn from the west. He had two things in mind then: one, China had to train talents with a good knowledge of western culture and science; two, it had to introduce advanced technology from the west to develop its national industry, communications and transportation. He started to run about, trying to seek possible means to this end. At that time Zeng Guofan was collecting people for his Westernization Movement. He issued an invitation to Rong Hong who, in response to his invitation, arrived in Anqing and joined Zeng in his campaign, in September, 1863.

Rong Hong suggested to Zeng Guofan that a machinery plant be set up and, as his suggestion coincided with Zeng's idea of opening a modern munitions factory in China, he entrusted him with the mission of purchasing machines abroad. In 1865 Rong Hong purchased over one hundred machines from the United States, which constituted the bulk of the equipment for Jiangnan General Manufacturing Bureau.

Besides, he directed full attention to the training of people well versed in western learning. Twice had he suggested that the Qing government send students to study in the United States and, over the following years, the Qing government, adopting his advice, sent 120 students on government funds and appointed Rong Hong as Vice Superintendent for overseas students affairs. (Translated by Liu Shicong)

Rong Hong is the first Chinese ever to have graduated from an American university. After graduating from Yale, he returns to China and devotes himself to the prosperity of his motherland. The paragraphs above describe Rong's major contributions to China, i.e., to introduce advanced technology and train talents. Though the Chinese text employs few connectives, it is well constructed with lexical cohesiveness and coherence as the underlined phrases show. The translator reconstructs the texture according to English textual convention (see the underlined words or phrases of the English version). And paragraph transition markers are appropriately rendered into English: 1) 容闳回国后, 看到了... If this sentence was translated as After he returned to China, Rong Hong witnessed ..., it would be all right. But when we take account of the last sentence in the previous paragraph, namely, 离开耶鲁后, 容 闳......回到了祖国的怀抱, such rendering is quite redundant. Liu's translation But Rong Hong returned only to witness... avoids redundancy, and makes a natural transition between paragraphs. 2) 到安庆后, 容闳向曾国藩提出了... Liu’s translation omits 到安庆后, but such omission is justified, because the last sentence in the previous paragraph (1863年9月, 容闳应邀到达安庆, 入曾国藩大营) has mentioned Rong's arrival at Anqing. Suppose “到安庆后” was rendered, it would sound unnecessary. 
3) 除了兴办近代工业企业, 容闪还十分注重... This sentence could be rendered as Besides establishment of modern industries, Rong... However, since paragraph (2) has elaborated on Rong's contribution to the establishment of modern industry in China, such rendering is inappropriate. Liu's translation Besides, Rong... is really a natural paragraph transition. To a certain degree, it is owing to the successful translation of transition markers that the English version has a good texture.

\section{Transferring Non-formal Aesthetic Markers}

The beauty of a literary work is not merely restricted to formal aesthetic markers. Non-formal makers also contribute to the aesthetic appeal. For instance, when reading Su Shi”s poem “大江东去, 浪淘尽千古风流人物” (苏轼《念奴娇.赤壁怀古》), one feels the beauty of the line, though the beauty is not in the individual words, but in the overall power and appeal which arouse the reader's thoughts on remote things (Liu Miqing 1995). This aesthetic appeal can be explained with the concept of yijing (意境), which in traditional Chinese aesthetics and literary criticism refers to a harmonious relationship between the writer's personal feeling and the outside world. The above-mentioned line does not simply describe an image, but embodies the feeling and thought of the writer.

In fact, the writer's feeling and thought play a significant role in non-formal aesthetic markers. According to Liu Xie (2008: 232), "Languages are like leaves of a tree, but the soul of a literary text is the writer's feeling and thought” (辞为肤叶, 志 实骨髓《体性》). Liu Shicong also points out:

The weightiness of a writing, however, is determined first and foremost by the profundity of the thought and the loftiness of the moral character on the part of the author, and its elegance and strength by the brevity, clarity and the appropriateness of syntactic structure (Liu Shicong 2000: 70).

Although non-formal markers are characterized by fuzziness, they are not something mysterious that cannot be analyzed. In a sense, non-formal aesthetic markers rely in large measure on the writer's personality. Hence before translating, the translator should try to familiarize himself with the writer, and feel the way the writer feels about what he writes. Only when the translator finds himself on the same wavelength as the writer can he understand the particular attitude of the writer and grasp the overall effect of the work, and reproduce non-formal aesthetic markers in another language. It is a demanding job for the translator to do so, but this does not mean that non-formal aesthetic markers cannot be translated. I will, in what follows, concentrate on the transference of imagery, of feeling and of tone to illustrate how competent translators successfully represent the non-formal aesthetic markers. (Nevertheless, non-formal aesthetic markers are not confined to these three aspects, but involve many other aspects, such as feel and flavor of the literary text. Here I only go into detail about the three important aspects.)

\subsection{Translating imagery}

Before our discussion about the transference of imagery, it is necessary for us to make clear what is imagery. Briefly, imagery is an aesthetic object created by the writer. It is not simply an image (either an object or a person), but is an artistic one that com- 
bines an objective image with the subjective feeling of the writer (“意象”是经过艺术 构思后形成的审美对象, 寄托着作者的思想感情。它并不等同于简单的物象 (人或 物), 而是融合主观的意 (情思) 和客观的象 (景物) 为一体的艺术形象). In a literary work, it is the imagery that attracts readers' attention and gives them aesthetic pleasure. In translating, it is essential for the translator to reproduce the original imagery, for its representation ensures the transference of artistic values of the original text. The Chinese literary translator Mao Dun says:

Literary translation is to reproduce the artistic imagery of the original in another language so that the reader of the translation may be inspired, moved and aesthetically entertained in the same way as they read the original (Liu Zhongde 1991: 104; with my revision of Liu's translation).

The importance of imagery transference can be illustrated by the following example:

(12) There was nobody. Her words faded. So a rocket fades. Its sparks, having grazed their way into the nights, surrender to it, dark descends, pours over the outlines of houses and towers; bleak hillsides soften and fall in. But though they are gone, the night is full of them; robbed of colour, blank of windows, they exist more ponderously, give out what the frank daylight fails to transmit - the trouble and suspense of things conglomerated there in the darkness; huddled together in the darkness; reft of the relief which dawn brings when, washing the walls white and grey, spotting each windowpane, lifting the mist from the fields, showing the redbrown cows peacefully grazing, all is once more decked out to the eye; exists again. I am alone; I am alone! She cried, by the fountain in Regent's Park (staring at the Indian and his cross), as perhaps at midnight, when all boundaries are lost, the country reverts to its ancient shape, as the Romans saw it, lying cloudy, when they landed, and the hills had no names and rivers wound they knew where - such was her darkness... (Virginia Woolf: Mrs Dalloway)

$\mathrm{V} 1$ : 四周了无人际。她的话音消失了, 仿佛火箭消失一般。它射出的火花胨过夜空, 淹没在夜色之中, 黑暗降临, 笼罩了房屋、尖塔的轮廓; 荒山两边的线条渐趋朦胧, 只留下漆黑一团。然而这一切虽不可见, 却依然蕴含在夜色之中; 尽管色彩已被吞 噬, 房屋上的窗户也不复再现, 它们却更深沉地存在着, 表现出阳光下无从传递的 意境——各种事物的烦恼及悬念, 在黑暗中闹聚在一起, 挤成一团。黑夜夺去了 黎明带给人们的宽慰。当曙光洗净四壁的黑暗, 照出每个窗户, 驱散田野上的薄 雾, 照见那些棕红色奶牛在安详地吃草, 一切事物重又整整齐齐地呈现于眼前, 恢复了生存。我子然一身, 多么孤寂! 孤零零地站在摄政公园喷水池边, 她呻吟着 (一面看着那印度人和他的十字架), 也许好似在夜半时分, 黑暗笼罩大地, 一切 界线都不复存在, 整个国土恢复到洪荒时期的形态, 宛如古罗马人登陆时见到的 那样, 宇宙一片混沌, 山川无名, 河水自流, 不知流向何方——这便是她内心的黑 暗。(Translated by Sun Liang)

$\mathrm{V} 2$ : 周围一个人都没有。她的话音转瞬即逝。犹如一枚火箭转瞬即逝。它射出的无 数火花在照亮长空之后终于退让了, 黑暗重又降临, 泼酒在众多房屋和高塔的轮 廓线上; 荒凉的山坡变得模糊不清, 最终陷入黑暗。然而尽管它们已经消逝, 夜空 仍将它们统统包容: 它们被剥夺了颜色, 从窗口消失了, 但它们仍以更加沉重的形 式存在着, 揭示出坦诚的日光所未能显现的东西——聚集在黑暗中、蜷缩在黑暗 中的万物那纷扰不定的状态, 全然失去了晨曦带来的欣慰感(晨曦将无数墙壁刷 成灰白, 点染每一块窗玻璃, 驱散田野上的薄雾, 显现出安静吃草的红褐色母牛, 那时世间的一切再次被装点得赏心悦目, 又重新存在)。就我一个人, 就我一个人! 她在摄政公园的喷泉旁喊道(同时凝视着那个印度人和他的十字架), 仿佛是在午 夜, 所有的疆界都消失了, 这个国家又回到古代的状况, 正如罗马人当时所见, 他 们登陆时, 这个国家正处于朦胧之中, 山脉无名, 河流蜿蜒不知流向何方-—她所 感到的黑暗就是如此; .......(Translated by Gu Qinan) 
The writer employs the symbolic imagery of darkness to describe Lucrezia's loneliness. She feels lonely because her husband is mad and yet she has no friends to talk to. The imagery of darkness appropriately reflects her feeling of loneliness and helplessness. In V1, this symbolic imagery is not satisfactorily rendered, for except the image of darkness there appears also the image of light (当曙光洗净四壁的黑暗, 照出每个窗户, 驱散田野上的薄雾, 照见那些棕红色奶牛在安详地吃草, 一切事物重 又整整齐齐地呈现于眼前, 恢复了生存。), which strikes a discordant note in the overall imagery. In V2, the image of light is put in brackets, indicating it is not the focus of this paragraph and meanwhile the image of darkness is highlighted. The translator Gu Qinan explains:

If this paragraph is viewed in context, the writer's focus is on creating an atmosphere of darkness. Though light is depicted in the original, it is not the focus of this paragraph, but the character's casual association, for it is a part of an adverbial clause that modifies an attributive clause. In order to ensure the transference of the imagery of "darkness" as the focus, the description of light is put in brackets in my translation, with the result that the shift of focus is avoided and the imagery of "darkness" is highlighted (Gu Qinan 1998: 3) ${ }^{1}$.

This example demonstrates the fact that the successful representation of imagery depends largely on the translator's sensitivity to the feeling that the writer intends to convey through the imagery.

\subsection{Translating feeling}

The beauty of a literary work not only lies in the language of the text, but also in the writer's feeling expressed through language. In a sense, any work of art is an expression of feeling. The French sculptor Rodin says that "art is feeling." Liu Xie even advocates “writing for feeling” (“为情而造文”《情采》), taking feeling as the fundamental basis of beauty in an article. Since the writer's feeling is an essential component of a literary work, it is very necessary for the translator to convey the writer's feeling. Let us look at an example:

（13）他便将家中事务一一的嘱托了族中人并几个老家人, 他便带了母妹竟自起身长行 去了。人命官司一事, 他竟视为儿戏, 自为化上几个臭钱, 没有不了的。 （曹雪芹《红楼梦》第4回）

Entrusting everything to his clansmen and a few old trusty retainers, he then proceeded to depart according to schedule, in company with his mother and sister, on the long journey to the capital, accounting the charge of manslaughter a mere bagatelle which the expenditure of a certain amount of coin could confidently be expected to resolve. (Translated by David Hawkes)

This paragraph was the author's narrative after Xue Pan ordered his servants to seize the girl Ying Lian and kill Feng Yuan, who had bought the girl as his wife from a man-trader, who sold the girl again to Xue Pan. After Feng was beaten to death, Xue departed for the capital according to original schedule as if nothing had happened. When reading such phrases as 竟视为儿戏, 几个臭钱, 没有不了的, we can feel the writer's indignation. By using such expressions as a mere bagatelle, a certain amount of coin and confidently be expected to resolve, the translator appropriately conveys the writer's condemnation of such scandal characteristic of the feudal society. 


\subsection{Translating tone}

It is difficult to transfer the content of a literary text, but it is even more difficult to translate the tone, because it is beyond the surface meaning of words. Nevertheless, it is of great necessity to produce the tone in literary translation. Mao Dun says:

If a translator cannot produce 'the tone of sentence' in the original, the spirit of the text cannot be fully conveyed in his translation [...] Therefore, I think the literary translator should pay more attention to the preservation of 'the tone of sentence' (Mao 1984: 97).

Huang Yushi (1988: 279) expresses a similar view in stating that if the translator uses the same tone to render the speeches of different characters in a novel, his rendering will end in failure even if the meaning of each sentence is "correctly" rendered. Take two Chinese renderings of the same paragraph from Huckleberry Finn for example:

(14) He (Jim) said he druther see the new moon over his left shoulder as much as a thousand times than take up a snake-skin in his hand. Well, I was getting to feel that way myself, though I've always reckoned that looking at the new moon over your left shoulder is one of the carelessest and foolishest things a body can do. (Mark Twain: Huckleberry Finn)

V1: 他说他宁可向左边看一千回月牙儿, 也不愿意用手拿一次蛇皮。我自己也渐渐 地以为如此了, 虽然我一向认为向左回头看月牙儿, 在一个人所作所为的当中, 要 算是最大意、最愚蚌的事情。

V2: 他说他宁愿向左转头看上一千次月牙儿, 也决不用手去摸一下蛇皮。是呀, 我 现在也觉得真是应该那样儿, 尽管以前我总认为向左转头看月牙儿是一个人可能 干出的最冒失、最愚蚌的事了。(Translated by Huang Yushi)

Because Jim touches a snake-skin, he has been ill for four days. So Finn decides to take Jim's advice not to touch a snake-skin. Though V1 conveys the basic sense of the original, it does not preserve the tone of the sentences. For instance, the tone between the two sentences 他说他宁可... and 我自己也渐渐地以为如此了 is unclear. 在一个人所作所为的当中 does not articulate appropriately the tone of Finn as a child (Huang 1988: 293). By contrast, V2 is a successful attempt, as the underlined words illustrate.

So far we have discussed transference of aesthetic values in terms of formal markers and non-formal markers respectively. However, in a literary work formal markers and non-formal markers are really inseparable. Robert J. Waller (1992: 47) in his The Bridges of Madison County says, "Analysis destroys wholes. Some things, magic things, are meant to stay whole. If you look at their pieces, they go away." Waller's assertion shows that it is of great importance to appreciate the beauty of a literary work as a whole. To illustrate the transference of aesthetic values of a literary text in terms of formal markers and non-formal markers, we may look at an essay $A$ Watering Place and its Chinese rendering:

(15) A Watering Place

Hayden

Saturday Night, 30 Sept. 1826

William Cobbett

(1) The Warwickshire Avon falls into the Severn here, and on the sides of both, for many miles back, there are the finest meadows that ever were seen. (2) In looking 
over them, and beholding the endless flocks and herds, one wonders what can become of all the meat! (3) By riding on about eight or nine miles farther however, this wonder is a little diminished; for here we come to one of the devouring WENS, namely, CHELTENHAM, which is what they call a "watering place," that is to say, a place to which East India plunderers, West India floggers, English taxgorgers, together with gluttons, drunkards, and debauchees of all descriptions, female as well as male, resort, at the suggestion of silently laughing quacks, in the hope of getting rid of the bodily consequences of their manifold sins and iniquities. (4) When I enter a place like this, I always feel disposed to squeeze up my nose with my fingers. (5) It is nonsense, to be sure; but I conceit that every two-legged creature, that I see coming near me, is about to cover me with the poisonous proceeds of its impurities. (6) To places like this come all that is knavish and all that is foolish and all that is base; gamesters, pick-pockets, and harlots; young wife-hunters in search of rich and ugly and old women, and young husband-hunters in search of rich and wrinkled or half-rotten men, the former resolutely bent, be the means what they may, to give the latter heirs to their lands and tenements. (7) These things are notorious; and, Sir William Scott, in his speech of 1802, in favour of the non-residence of the Clergy, expressly said, that they and their families ought to appear at watering places, and that this was amongst the means of making them respected by their flocks! (8) Memorandum: he was a member for Oxford when he said this!

(2) 温泉胜地

海顿

1826年6月30日, 星期六晚 威廉·科贝特

(1) 华立克夏的爱望河在此处流入色纹河, 两河沿岸若干哩水草丰美, 前所未见。

(2) 草地上牛羊成群, 沿途不断。(3) 看着这景色, 这牛羊, 心想这些好肉可作多少 用途, 不禁感到神奇。(4) 但是再向前骑八九哩, 这神奇之感就破灭了, 原来我们 已到达一个毒瘤似的害人地方, 名叫却尔特能, 所谓温泉胜地是也。(5) 这地方充 满了东印度的劫掠者, 西印度的奴隶主, 英国的税吏, 吃客, 酒鬼, 淫棍, 各色各 样, 男女俱全。(6) 他们听了一些窃窃暗笑的江湖郎中的鬼话, 以为在做了多少丑事 之后, 一身蔁障, 可以到此一洗而净! (7) 我每次进入这等地方, 总想用手指捏住自 己的鼻子。(8) 当然这话没有道理, 但我一看见这儿任何一个两腿畜生向我走来, 实在觉得他们肮脏不堪, 象是一有机会就要将他们的毒疮传染给我似的! (9) 来 这等地方的都是最恶劣、最愚蚌、最下流的人: 奢鬼, 小偷, 娼妓, 一心想娶有钱 的丑老婆子的年轻男子, 一心想嫁有钱的满脸皱纹、半身入土的老头子的年轻女 人, 这些少夫幼妻为了便于承继产业, 不惜一切手段, 坚决要为这些老妇衰翁生 男育女! (10) 这等丑事, 尽人皆知。(11) 然而威廉司各特爵士在1802年演讲, 明白 主张牧师不必定居教区,而应携漛到温泉游览，据说这样反而能得到他们教区子 民的尊敬云云。(12) 查此人作此语时, 官任代表牛津城的国会议员! (Translated by Wang Zuoliang)

This English essay describes a beautiful scenic spot, the so-called watering place, to which various notorious persons such as gamesters, pick-pockets, harlots resort. The writer shows his disgust at this place with biting sarcasm. The translator succeeds in conveying the ironical tone of the original text. For instance, in sentence (8) Memorandum: he was a member for Oxford when he said this!, Memorandum is a formal expression used in international affairs. By putting it as 查此人作此语时, which is an equivalent Chinese official rhetoric, the translator reproduces the spirit of the original text at lexical level. If it was rendered as 备忘录, its ironical spirit could not be kept in Chinese, and the whole translation would lose too much flavor (Yuan 
1990: 359). 所谓温泉胜地是也 for what they call a 'watering place,' and 这等地方 for a place like this and To places like this represent vividly the writer's disgusting feeling toward this notorious watering place. In terms of rhetorical devices, the hyperbolic expression To places like this come all that is knavish and all that is foolish and all that is base is satisfactorily rendered as 来这等地方的都是最恶劣 最愚蚌、最下流 的人 with a similar emphasis upon the three types of persons. The succinct parallelism young wife-hunters in search of rich and ugly and old women, and young husbandhunters in search of rich and wrinkled or half-rotten men is also appropriately put as the Chinese parallel structures 一心想娶有钱的丑老婆子的年轻男子, 一心想嫁有 钱的满脸皱纹、半身入土的老头子的年轻女人. Long sentences are skillfully handled as well. Take the English sentence (3) for example. It contains ninety words, but the translator replaces it with four short Chinese sentences [(4), (5), (6) in the Chinese version], which ensure the readability and naturalness of the Chinese version. By adding necessary conjunctions and repetitions (such as 但是... and 原来... in sentence (4), and 这地方 and 他们 in sentence (5), the translator makes his version cohesive and coherent. As Yuan Jinxiang (1990: 358) rightly remarks, Wang's handling of long sentences avoids stylistically awkwardness, and allows the Chinese reader to understand the meaning with ease and efficiency. In terms of the transference of non-formal markers, the translation successfully represents the ironic tone which pervades the original text. The translator grasps the spirit of the original, and conveys it in every word and every sentence. The success of this Chinese rendering can be best explained in the translator's own words,

When the translator grasps the imagery, mood or effect of a literary text as a whole, he will find that some minor alterations of individual details do not affect the transference of the overall effect of his translation (Wang Zuoliang 1989: 74).

Nevertheless, the emphasis on wholeness does not necessarily mean that the translator need not pay due attention to details. Rather, the successful representation of the overall artistic effect of the text in a literary translation consists in transferring accurately the details, such as words, syntactical structures and rhetorical devices. As the example above proves, the proper combination of the two can provide a satisfactory solution to the successful representation of aesthetic values in literary translation.

\section{NOTES}

1. Gu, Qinan (1998): Applying the Theory of 'Functional Equivalence' to Chinese Translation of Mrs. Dalloway, unpublished. Conference on Translation Studies and Teaching, Tianjin, $23^{\text {rd }}-25^{\text {th }}$ October, 1998.

2. Paine, Thomas (1776): The Crisis. Visited 25 September 2009, <http://www.ushistory.org/PAINE/ crisis/singlehtml.htm>.

\section{REFERENCES}

Huang, Yushi (1988): Exploring Literary Translation Between English and Chinese. Xi'an: Shanxi People's Press.

Kelly, Louis G. (1979): The True Interpreter: A History of Translation Theory and Practice in the West. Oxford: Basil Blackwell.

LEECH, Geoffrey N. and SHORT, Michael (1981): Style in Fiction. London: Longman. 
Liv, Miqing (1995): Aesthetics and Translation. In: Chan Sin-wai and David E. Pollard, eds. An Encyclopedia of Translation. Hong Kong: Chinese University Press, 1-13.

LIU, Shicong (2000): Reading and the Translator. NanKai Journal. Supplement: 69-75.

LiU, Xie (2008): Carving a Dragon at the Core of Literature. Kaifeng: He Nan University Press.

LiU, Zhongde (1991): Ten Lectures on Literary Translation. Beijing: China Translation and Publishing Corporation.

MaO, Dun (1984): Methods of Literary Translation. In: Translator's Notes, ed. Essays on Translation Studies (1894-1948). Beijing: Foreign Language Teaching and Research, 93-98.

NidA, Eugene A. (1964): Towards a Science of Translating: with Special Reference to Principles and Procedures Involved in Bible Translating. Leiden: Brill.

NidA, Eugene A. (1982): Translating Meaning. San Dimas: English Language Institute.

Paine, Thomas (2006): The American Crisis. Teddington: The Echo Library.

Snell-Hornby, Mary (1988): Translation Studies: An Integrated Approach. Amsterdam: John Benjamins.

Strunk, William and White, Elwyn Brooks (1972): The Elements of Style. New York: Macillan.

WALler, Robert J. (1992): The Bridges of Madison County. Beijing: Foreign Languages Press.

WANG, Zuoliang (1989): Translation: Experiments and Reflections. Beijing: Foreign Language Teaching and Research Press.

Wu, Jingrong, Ding, Wangdao, and QIAN, Qing, eds. (1980): Readings in Modern English Prose. Beijing: Commercial Press.

Xu, Yuanchong (1989): The Art of Translation. Beijing: China Translation and Publishing Corporation.

YuAN, Jinxiang (1990): Study and Appreciation of Translated Works by Renowned Translators. Wuhan: Hubei Education Press.

Zhang, Jin (1987): Principles of Literary Translation. Kaifeng: Henan University Press.

ZHu, Guangqian (1984): On Translation. In: Translator's Notes, eds. Essays on Translation Studies(1894-1948). Beijing: Foreign Language Teaching and Research Press, 353-363. 